\title{
S100A Family Proteins and Mesothelin in Tear Proteome Are Associated With Retinal Vein Occlusion
}

\author{
Alexander Stepanov \\ Institute of Biomedical Chemistry \\ Svetlana Usharova \\ Russian Medical Academy of Continuous Professional Education \\ Kristina Malsagova \\ Institute of Biomedical Chemistry \\ Larisa Moshetova \\ Russian Medical Academy of Continuous Professional Education \\ Ksenia Turkina \\ Russian Medical Academy of Continuous Professional Education \\ Arthur Kopylov ( $\nabla$ a.t.kopylov@gmail.com ) \\ Institute of Biomedical Chemistry \\ Anna Kaysheva \\ Institute of Biomedical Chemistry
}

\section{Research Article}

Keywords: retinal vein occlusion, retinal hemostasis, S100A protein, mesothelin, inflammation

Posted Date: October 21st, 2021

DOI: https://doi.org/10.21203/rs.3.rs-989916/v1

License: (ㅇ) This work is licensed under a Creative Commons Attribution 4.0 International License. Read Full License 


\section{Abstract}

Tear samples were collected from 88 subjects and analyzed using absolute quantitative and comparative proteomic approach. We found a large proportion (505 proteins) of tear proteome between healthy donors and subjects with retinal vein occlusion (RVO). Comparative proteomic analysis revealed 30 proteins $(p<0.05)$ significantly differed in their quantitative property. Among them S100A6 (3.7 fmoles $/ \mathrm{ng}, p<0.001)$, S100A8 (0.68 fmoles/ng, $p<0.001)$, and S100A9 (2.06 fmoles/ng, $p<0.001)$ are the most overrepresented proteins. Mesothelin was found as tear-specific protein with significant increase $(1.08 \mathrm{fmoles} / \mathrm{hg}$ versus $0.54 \mathrm{fmoles} / \mathrm{ng}$ in the control, $p<0.001)$ in the RVO group. The selected altered proteins were combined to reconstruct the customized map of protein-protein interactions with the burden of quantitating property and the context of RVO-related association. The customized interactions map (FDR<0.01) emerged inflammation and impartment of retinal hemostasis as the main RVO-associated processes. The semantic analysis of customized map encouraged the prevalence of core biological processes encompassing dysregulation of mitochondrial organization and utilization of topologically incorrect folded proteins as a consequence of oxidative stress and inflammation caused by the retinal ischemic condition. Significantly differed proteins (S100A6, S100A8, S100A9, MSL, B2M) were applied for the ROC plotting with AUC varied from 0.772 to 0.952 suggesting their association with the CRVO.

\section{Introduction}

Retinal vein occlusion (RVO) is a frequent ocular disease that is fraught with a risk of blindness or severe decrease of visual acuity since the entire retina is affected especially in older patients ${ }^{1,2}$. While the progression of RVO, the retinal is likely to suffer ischemic condition upstream of the occlusion, entailing to the increase of inflammatory proteins ${ }^{3}$.

Tear fluid proteomics assays confirmed the correlation between chronic eye diseases and clinical effects of aging. Turning to the panoply of results, it has been hypothesized that the tear proteome is featured by the age-associated gradual increase of inflammatory proteins and immune response cytokines. Several cytokines, including interleukin- 6 and VEGF (vascular endothelial growth factor), are known to be associated with RVO but still, it contributes little in understanding of RVO pathology. The objection is limited to the high interindividual variability of cytokines and sensitivity to the epigenetic background ${ }^{4,5}$. A comparative tear proteomic study of $30 \mathrm{RVO}$ patients with age-related macular degeneration demonstrated significant enrichment by complement factors (C3 and C9), clusterin (CLU), S100A9, and S100A8 proteins ${ }^{6}$. A deficiency of glucose-6-phosphate dehydrogenase (G6PD) serum level has been correlated with a risk of CRVO due to the increased vulnerability to oxidative stress ${ }^{7}$. The S100A12 has also been considered as a contributor to the inflammation response at the ischemic condition of RVO. At least in the animal model of RVO, a five-fold increase of S100A12 has been found in retinal ganglion cells and their dendritic processes and confirmed by the Western blot analysis ${ }^{8}$. A relative abundance of S100A family proteins suggests an indication of the ongoing inflammation following the RVO and the consequent ischemic condition ${ }^{9}$. However, neither of these studies yielded a rational understanding of the molecular basis of CRVO. 
Another side of eye-related proteomic investigation is focused on the mitochondria-associated proteins. A study of proteome after laser-induced retinal artery occlusion (RAO) relevant to clinical manifestation figured out an increased abundance of Bax protein, and simultaneous elevation of cytosolic cytochrome $c$ and caspase-9 suggesting a severe and rapid escalation of oxidative stress accompanied by mitochondrial dysfunction and pro-apoptotic events ${ }^{10}$. Dysfunction of mitochondrial ATP generation was found in the proteome of retinal pigment epithelium obtained from patients with age-related macular degeneration, and in in vitro models of human embryonic stem cells ${ }^{11-13}$. Notwithstanding, dysregulation of mitochondria functioning reflects the consequence of RVO but does not determine the root of pathology.

Proteomic study of eye diseases is a challenging task low stability of such biomaterial. While modern approaches can achieve a size of proteome accounting up to 5,000 proteins, this information can be not highly promising and carry no information regarding the discovery of biomarkers since routine proteomic assay requires a large dataset to improve results reproducibility. One of the critical issues is samples collection and storage standardization requirement; another challenge is the high sensitivity of proteomics to individual variability. The latter causes poor identification of well-known RVO associated markers (such as ICAM1), whereas other proteins of particular interest are mostly characterized by inflammatory and immune-response activities ${ }^{14}$.

This study purposed to find the answer to whether is it possible to distinguish patients with CRVO by their proteome, and whether is it possible to pick up certain key proteins that clue the treatment strategy or disease onset? To make a better understanding of molecular pathways associated with CRVO, we conducted a quantitative proteomic measurement and compiled it with the reconstruction of the diseasetargeted protein-protein interactions mapping.

\section{Results}

The proteomic analysis discovered 710 and 682 protein identifications on the control and examined CRVO group, respectively, thus the proteome dimensionality between two groups is equilibrium condition. The shared part of the proteome comprised of 505 protein identifications, or more than $70 \%$ of individual proteome size. Despite the proportional size of aggregated proteomes within groups, the distribution of individual proteomes was unequal and made 275 proteins (median) in the control group and 154 proteins (median) in the CRVO group (Figure 1A). At the same time, group-specific proteins were found to be the least frequent and consisted of 0.37 (median value) and 0.15 amongst subjects in the control and CRVO groups, correspondingly (Figure 1B) while the median frequency of protein in the aggregated proteome consisted 0.5 and 0.23 in the control and CRVO group, respectively.

Quantitative analysis demonstrated a similar distribution of measured proteins in both studied groups. It was found, that proteins are distributed along with four orders of magnitude covering the dynamic range of concentrations between 0.01 and $100 \mathrm{fmoles} / \mathrm{ng}$. The majority of proteins were attributed to mediumcopied (between 0.1 and $10 \mathrm{fmoles} / \mathrm{ng}$ ), whereas a small portion was divorced between low-copied (0.01$0.1 \mathrm{fmoles} / \mathrm{ng}$ ) and high-copied (more than $10 \mathrm{fmoles} / \mathrm{mL}$ ) in both studied groups (Figure 2A). The least abundant protein was found TMSB10 $(0.0132 \mathrm{fmoles} / \mathrm{mL})$ in the CRVO group and ITPR1 (0.0339 
fmoles $/ \mathrm{mL}$ ) in the control group; the most abundant proteins were CDC14C (158 fmoles $/ \mathrm{mL})$ and LTF (108 fmoles $/ \mathrm{mL}$ ) in the OCRV and control groups, respectively.

The obtained result of concentration-dependent proteins normal distribution (Figure 2A) and similar proteomes dimensionality suggests uniform in-depth discovery and proportional quantitative loading of proteins between studied groups.

The principal component analysis did not demonstrate a satisfied separation between the examined group of patients and the control group. The groups under consideration almost completely overlapped with a variance of PC1 made $12.84 \%$ and PC2 made $8.4 \%$ (Figure 2 C).

To unveil the difference between groups of study, we selected 137 mutual proteins with a frequency exceeding 0.6 in both control and CRVO groups. Of them, only 31 proteins passed the significance cut-off ( $p$ $<0.05$ ), and this fraction comprised of 9 down-regulated (including three Ig-heavy and two Ig-light chains) and 22 up-regulated proteins in the CRVO patients compared to healthy donors (Table 2 and Figure 2B). Biological processes analysis (significance cut-off $p<0.001$ ) showed (Figure 3 ) that the majority of proteins are not highly-specialized and covers the regulation of cellular response to misfolded proteins $(p=2.31 \mathrm{e}$ $04)$, cellular response to topologically incorrect protein $(p=4.77 \mathrm{e}-04)$, and positive regulation of mitochondrion organization ( $p=9.91 \mathrm{e}-04)$. Molecular functions mapping affirmed the prevalence of cell stress-responsive proteins since the main proportion of proteins are characterized by ubiquitin $(p=6.96 \mathrm{e}-06)$ and ubiquitin-like ligase binding activity $(p=1.49 \mathrm{e}-04)$. 
Table 1

Quantitative assessment of the shared part of proteome $(p<0.05)$. Due to the frequency percolation (more than 0.6 value within each group) has been applied prior to the selection of significant proteins, the estimated concentration is designed as a median value with an inter quartile (q1-q3) range (IQR). The protein concentration is estimated as an amount of certain protein (in fmoles) per one ng of total protein on-column loading. The total amount of protein on-column loading was 3 (three) $\mu \mathrm{g}$ per a sample.

\begin{tabular}{|c|c|c|c|c|c|c|c|c|}
\hline \multicolumn{3}{|l|}{ Identifiers } & \multicolumn{2}{|c|}{ Frequency } & \multicolumn{2}{|c|}{$\begin{array}{l}\text { Concentration } \\
\text { (median } \pm \text { IQR), } \\
\text { fmoles/ng }\end{array}$} & \multirow[t]{2}{*}{$\begin{array}{l}\mathrm{FC} \\
\text { log2 }\end{array}$} & \multirow[t]{2}{*}{$\begin{array}{l}p- \\
\text { value }\end{array}$} \\
\hline Accession & Gene & $\begin{array}{l}\text { Recommended } \\
\text { name }\end{array}$ & CRVO & Control & CRVO & Control & & \\
\hline P61769 & B2M & $\begin{array}{l}\beta 2- \\
\text { microglobulin }\end{array}$ & 0.88 & 0.90 & $\begin{array}{l}2.32 \\
\pm \\
2.16\end{array}$ & $\begin{array}{l}12.94 \\
\pm \\
10.19\end{array}$ & -2.48 & $\begin{array}{l}1.49 \mathrm{E}- \\
10\end{array}$ \\
\hline P60709 & ACTB & $\begin{array}{l}\text { Actin } \\
\text { cytoplasmic } 1\end{array}$ & 1.00 & 1.00 & $\begin{array}{l}5.68 \\
\pm \\
10.45\end{array}$ & $\begin{array}{l}14.03 \\
\pm 8.5\end{array}$ & -1.3 & $\begin{array}{l}4.67 \mathrm{E}- \\
03\end{array}$ \\
\hline Q96DA0 & ZG16B & $\begin{array}{l}\text { Zymogen } \\
\text { granule protein } \\
16 \text { homolog B }\end{array}$ & 0.73 & 0.73 & $\begin{array}{l}1.29 \\
\pm \\
1.22\end{array}$ & $\begin{array}{l}2.61 \pm \\
3.2\end{array}$ & -1.02 & $\begin{array}{l}3.86 \mathrm{E}- \\
03\end{array}$ \\
\hline P01859 & IGHG2 & $\begin{array}{l}\text { Immunoglobulin } \\
\text { heavy Y2 }\end{array}$ & 0.98 & 1.00 & $\begin{array}{l}6.92 \\
\pm \\
12.19\end{array}$ & $\begin{array}{l}13.95 \\
\pm 12.1\end{array}$ & -1.01 & $\begin{array}{l}7.62 \mathrm{E}- \\
04\end{array}$ \\
\hline P01860 & IGHG3 & $\begin{array}{l}\text { Immunoglobulin } \\
\text { heavy Y3 }\end{array}$ & 0.98 & 0.97 & $\begin{array}{l}0.56 \\
\pm \\
1.02\end{array}$ & $\begin{array}{l}0.94 \pm \\
1.56\end{array}$ & -0.75 & $\begin{array}{l}2.20 \mathrm{E}- \\
02\end{array}$ \\
\hline P02790 & HPX & Hemopexin & 0.92 & 0.97 & $\begin{array}{l}2.05 \\
\pm 2.2\end{array}$ & $\begin{array}{l}3.21 \pm \\
4.78\end{array}$ & -0.65 & $\begin{array}{l}1.23 \mathrm{E}- \\
02\end{array}$ \\
\hline AOAOAOMRZ7 & $\begin{array}{l}\text { IGKV2D- } \\
26\end{array}$ & $\begin{array}{l}\text { Immunoglobulin } \\
\text { K-variable 2D-26 }\end{array}$ & 0.67 & 0.73 & $\begin{array}{l}1.58 \\
\pm \\
1.07\end{array}$ & $\begin{array}{l}2.32 \pm \\
1.86\end{array}$ & -0.56 & $\begin{array}{l}2.14 \mathrm{E}- \\
02\end{array}$ \\
\hline P0DOY3 & IGLC3 & $\begin{array}{l}\text { Immunoglobulin } \\
\lambda 3\end{array}$ & 1.00 & 1.00 & $\begin{array}{l}27.18 \\
\pm \\
18.81\end{array}$ & $\begin{array}{l}34.93 \\
\pm \\
20.84\end{array}$ & -0.36 & $\begin{array}{l}1.12 \mathrm{E}- \\
02\end{array}$ \\
\hline P01591 & JCHAIN & $\begin{array}{l}\text { Immunoglobulin } \\
\text { J chain }\end{array}$ & 1.00 & 1.00 & $\begin{array}{l}10.97 \\
\pm \\
9.35\end{array}$ & $\begin{array}{l}11.62 \\
\pm 16.8\end{array}$ & -0.08 & $\begin{array}{l}4.00 \mathrm{E}- \\
02\end{array}$ \\
\hline P10909 & CLU & Clusterin & 1.00 & 0.97 & $\begin{array}{l}5.37 \\
\pm \\
5.61\end{array}$ & $\begin{array}{l}4.86 \pm \\
4.69\end{array}$ & 0.14 & $\begin{array}{l}4.83 \mathrm{E} \\
02\end{array}$ \\
\hline P22079 & LPO & Lactoperoxidase & 0.75 & 0.67 & $\begin{array}{l}0.75 \\
\pm 0.6\end{array}$ & $\begin{array}{l}0.53 \pm \\
0.33\end{array}$ & 0.51 & $\begin{array}{l}1.61 \mathrm{E}- \\
02\end{array}$ \\
\hline P04792 & HSPB1 & $\begin{array}{l}\text { Heat shock } \\
\text { protein } \beta 1\end{array}$ & 0.96 & 0.97 & $\begin{array}{l}2.05 \\
\pm 4\end{array}$ & $\begin{array}{l}1.38 \pm \\
1.25\end{array}$ & 0.57 & $\begin{array}{l}9.48 \mathrm{E}- \\
03\end{array}$ \\
\hline
\end{tabular}




\begin{tabular}{|c|c|c|c|c|c|c|c|c|}
\hline \multirow{2}{*}{$\begin{array}{l}\text { Identifiers } \\
\text { Accession }\end{array}$} & \multirow[b]{2}{*}{ Gene } & \multirow[b]{2}{*}{$\begin{array}{l}\text { Recommended } \\
\text { name }\end{array}$} & \multicolumn{2}{|c|}{ Frequency } & \multicolumn{2}{|c|}{$\begin{array}{l}\text { Concentration } \\
\text { (median } \pm \text { IQR), } \\
\text { fmoles/ng }\end{array}$} & \multirow[t]{2}{*}{$\begin{array}{l}\mathrm{FC} \\
\log 2\end{array}$} & \multirow[t]{2}{*}{$\begin{array}{l}p- \\
\text { value }\end{array}$} \\
\hline & & & CRVO & Control & CRVO & Control & & \\
\hline Q16378 & PRR4 & $\begin{array}{l}\text { Proline-rich } \\
\text { proteins } 4\end{array}$ & 0.73 & 0.73 & $\begin{array}{l}45.02 \\
\pm \\
53.69\end{array}$ & $\begin{array}{l}30.01 \\
\pm \\
25.78\end{array}$ & 0.59 & $\begin{array}{l}1.22 \mathrm{E}- \\
02\end{array}$ \\
\hline P19652 & ORM2 & $\begin{array}{l}\text { a1-acid } \\
\text { glycoprotein } 2\end{array}$ & 0.96 & 0.93 & $\begin{array}{l}1.65 \\
\pm \\
1.87\end{array}$ & $\begin{array}{l}1.08 \pm \\
1.36\end{array}$ & 0.62 & $\begin{array}{l}3.97 \mathrm{E}- \\
02\end{array}$ \\
\hline P02647 & APOA1 & $\begin{array}{l}\text { Apolipoprotein } \\
\text { A-I }\end{array}$ & 1.00 & 0.97 & $\begin{array}{l}6.39 \\
\pm \\
12.54\end{array}$ & $\begin{array}{l}4.11 \pm \\
6.92\end{array}$ & 0.64 & $\begin{array}{l}3.93 \mathrm{E}- \\
02\end{array}$ \\
\hline P02787 & TF & Serotransferrin & 1.00 & 1.00 & $\begin{array}{l}13.74 \\
\pm \\
16.56\end{array}$ & $\begin{array}{l}8.73 \pm \\
9.91\end{array}$ & 0.65 & $\begin{array}{l}2.56 \mathrm{E}- \\
02\end{array}$ \\
\hline P01023 & A2M & $\begin{array}{l}\text { a2- } \\
\text { macroglobulin }\end{array}$ & 0.65 & 0.83 & $\begin{array}{l}1.58 \\
\pm \\
1.11\end{array}$ & $\begin{array}{l}0.99 \pm \\
0.93\end{array}$ & 0.67 & $\begin{array}{l}1.32 \mathrm{E}- \\
02\end{array}$ \\
\hline POCOL4 & C4A & $\begin{array}{l}\text { Complement C4- } \\
\text { A }\end{array}$ & 0.58 & 0.70 & $\begin{array}{l}0.86 \\
\pm \\
0.58\end{array}$ & $\begin{array}{l}0.53 \pm \\
0.55\end{array}$ & 0.71 & $\begin{array}{l}1.93 \mathrm{E}- \\
03\end{array}$ \\
\hline P25311 & AZGP1 & $\begin{array}{l}\text { Zinc-a2- } \\
\text { glycoprotein }\end{array}$ & 1.00 & 1.00 & $\begin{array}{l}49.09 \\
\pm \\
14.46\end{array}$ & $\begin{array}{l}29.88 \\
\pm \\
19.63\end{array}$ & 0.72 & $\begin{array}{l}2.02 \mathrm{E}- \\
07\end{array}$ \\
\hline P01036 & CST4 & Cystatin-S & 1.00 & 0.97 & $\begin{array}{l}22.6 \\
\pm \\
9.75\end{array}$ & $\begin{array}{l}13.64 \\
\pm \\
11.91\end{array}$ & 0.73 & $\begin{array}{l}1.61 \mathrm{E}- \\
03\end{array}$ \\
\hline Q9UGM3 & DMBT1 & $\begin{array}{l}\text { Deleted in } \\
\text { malignant brain } \\
\text { tumors } 1 \text { protein }\end{array}$ & 0.83 & 0.97 & $\begin{array}{l}12.57 \\
\pm \\
10.37\end{array}$ & $\begin{array}{l}7.44 \pm \\
7.51\end{array}$ & 0.76 & $\begin{array}{l}1.82 \mathrm{E}- \\
03\end{array}$ \\
\hline P02763 & ORM1 & $\begin{array}{l}\text { a1-acid } \\
\text { glycoprotein } 1\end{array}$ & 0.96 & 0.97 & $\begin{array}{l}6.38 \\
\pm 9\end{array}$ & $\begin{array}{l}3.4 \pm \\
5.11\end{array}$ & 0.91 & $\begin{array}{l}3.19 \mathrm{E}- \\
02\end{array}$ \\
\hline P01034 & CST3 & Cystatin-C & 0.90 & 0.60 & $\begin{array}{l}1.54 \\
\pm \\
0.91\end{array}$ & $\begin{array}{l}0.81 \pm \\
1.1\end{array}$ & 0.92 & $\begin{array}{l}8.46 \mathrm{E}- \\
03\end{array}$ \\
\hline Q13421 & MSLN & Mesothelin & 0.81 & 0.83 & $\begin{array}{l}1.08 \\
\pm \\
0.74\end{array}$ & $\begin{array}{l}0.54 \pm \\
0.46\end{array}$ & 0.98 & $\begin{array}{l}1.44 \mathrm{E}- \\
04\end{array}$ \\
\hline Q99935 & OPRPN & $\begin{array}{l}\text { Opiorphin } \\
\text { prepropeptide }\end{array}$ & 1.00 & 0.97 & $\begin{array}{l}48.43 \\
\pm \\
38.04\end{array}$ & $\begin{array}{l}23.95 \\
\pm \\
29.76\end{array}$ & 1.02 & $\begin{array}{l}5.92 \mathrm{E}- \\
04\end{array}$ \\
\hline
\end{tabular}




\begin{tabular}{|c|c|c|c|c|c|c|c|c|}
\hline \multirow{2}{*}{$\begin{array}{l}\text { Identifiers } \\
\text { Accession }\end{array}$} & \multirow[b]{2}{*}{ Gene } & \multirow[b]{2}{*}{$\begin{array}{l}\text { Recommended } \\
\text { name }\end{array}$} & \multicolumn{2}{|c|}{ Frequency } & \multicolumn{2}{|c|}{$\begin{array}{l}\text { Concentration } \\
\text { (median } \pm \text { IQR), } \\
\text { fmoles/ng }\end{array}$} & \multirow[t]{2}{*}{$\begin{array}{l}\mathrm{FC} \\
\text { log2 }\end{array}$} & \multirow[t]{2}{*}{$\begin{array}{l}p- \\
\text { value }\end{array}$} \\
\hline & & & CRVO & Control & CRVO & Control & & \\
\hline P06703 & S100A6 & Protein S100-A6 & 1.00 & 0.90 & $\begin{array}{l}8.62 \\
\pm \\
18.84\end{array}$ & $\begin{array}{l}3.7 \pm \\
2.43\end{array}$ & 1.22 & $\begin{array}{l}6.00 \mathrm{E}- \\
05\end{array}$ \\
\hline P80303 & NUCB2 & Nucleobindin-2 & 0.63 & 0.60 & $\begin{array}{l}0.91 \\
\pm \\
0.78\end{array}$ & $\begin{array}{l}0.37 \pm \\
0.22\end{array}$ & 1.29 & $\begin{array}{l}2.15 \mathrm{E}- \\
06\end{array}$ \\
\hline P02766 & TTR & Transthyretin & 0.88 & 0.53 & $\begin{array}{l}0.78 \\
\pm \\
0.78\end{array}$ & $\begin{array}{l}0.27 \pm \\
0.21\end{array}$ & 1.51 & $\begin{array}{l}8.87 \mathrm{E}- \\
06\end{array}$ \\
\hline P06702 & S100A9 & Protein S100-A9 & 1.00 & 0.90 & $\begin{array}{l}8.71 \\
\pm \\
17.68\end{array}$ & $\begin{array}{l}2.06 \pm \\
1.19\end{array}$ & 2.08 & $\begin{array}{l}9.50 \mathrm{E}- \\
14\end{array}$ \\
\hline P05109 & S100A8 & Protein S100-A8 & 0.98 & 0.83 & $\begin{array}{l}3.35 \\
\pm \\
7.88\end{array}$ & $\begin{array}{l}0.68 \pm \\
0.62\end{array}$ & 2.3 & $\begin{array}{l}1.75 \mathrm{E}- \\
12\end{array}$ \\
\hline
\end{tabular}


Table 2

Main clinical and anthropometric characteristics of subjects of CRVO group and relevant control group.

\begin{tabular}{|c|c|c|c|c|c|}
\hline Parameter & \multicolumn{3}{|c|}{ CRVO group } & Control group & p-value ${ }^{\ddagger}$ \\
\hline Population size & \multicolumn{3}{|l|}{58} & 30 & - \\
\hline Gender ratio (M/F) & \multicolumn{3}{|c|}{$31 / 27(53 \% / 47 \%)$} & $20 / 10(67 \% / 33 \%)$ & 0.2 \\
\hline Diagnosis & $O D$ & os & OU & \multirow[t]{4}{*}{-} & \multirow[t]{4}{*}{-} \\
\hline Incomplete occlusion & 8 & 6 & - & & \\
\hline Thrombosis & 4 & 6 & - & & \\
\hline Occlusion & 20 & 12 & 2 & & \\
\hline Age, median (range), years old & \multicolumn{3}{|c|}{$61.5(40-89)$} & $77.5(61-86)$ & $<0.001$ \\
\hline Myocardial ischemia & \multicolumn{3}{|l|}{14} & 6 & \multirow[t]{4}{*}{ - } \\
\hline Diabetes mellitus (type 2) & \multicolumn{3}{|l|}{2} & - & \\
\hline Hypertensive disease & \multicolumn{3}{|l|}{48} & 29 & \\
\hline Anticoagulant medication & \multicolumn{3}{|l|}{13} & - & \\
\hline \multicolumn{6}{|l|}{ Cholesterol level, mmol/L } \\
\hline less than $5 \mathrm{mmol} / \mathrm{L}$ & \multicolumn{3}{|c|}{$33(57 \%)$} & 30 & \multirow[t]{3}{*}{-} \\
\hline 5-7 mmol/L & \multicolumn{3}{|c|}{$18(31 \%)$} & - & \\
\hline more than $7 \mathrm{mmol} / \mathrm{L}$ & \multicolumn{3}{|c|}{$7(12 \%)$} & - & \\
\hline
\end{tabular}

The enrichments analysis unfurled the prevalence of proteins implicated in the retina homeostasis (GO:0001895; $p=6.06 \mathrm{e}-18 ; \mathrm{FDR}=1.06 \mathrm{e}-13)$, humoral immune response (G0:0006959; $p=6.18 \mathrm{e}-08 ; \mathrm{FDR}$ $=7.73 \mathrm{e}-05)$, and defense response (G0:0006952; $p=3.39 \mathrm{e}-07 ; \mathrm{FDR}=3.30 \mathrm{e}-04)$. Expectedly, most of the observed proteins can be qualified as secreted and can be found in tear and tear glands $(p=7.72 \mathrm{e}-15)$, saliva $(p=4.65 \mathrm{e}-21)$, bone marrow cells $(p=5.39 \mathrm{e}-11)$, blood platelets $(p=2.44 \mathrm{e}-07)$, submandibular glands ( $p=9.25 \mathrm{e}-05)$, and can be attributed as residents in right and left atrium tissue ( $p=5.79 \mathrm{e}-05)$. The wide tissue distribution and multifunctional attributes evidence that the large proportion of significantly differed proteins are poorly specialized, but may play a pivotal role in different biological processes, particularly, in immune response and hemostasis maintenance.

We conducted protein-protein interaction analysis in support of Cytoscape using the STRING-based and disease-based model to reconstruct a proteins network tightly associated with the retinal vein occlusion as a target pathology. For this purpose, the final network was percolated to eliminate missed interaction and 
those proteins falling low molecular specialization. Eventually, only proteins with a high confidence score (at least 0.7 ), falling the criteria of implication in retinal vein occlusion (onset or progression) and being attributed to eye tissue, tear gland, or tear were selected to build the final proposed network (Figure 4).

Despite the small proportion of the examined proteins, almost a complete set (Table 1) participated in the network reconstruction with high confidence (more than 0.7 confidence score). The designed network can be divided into four large clusters, of which three are with tissue-specific attributes (eye, tear, and tear gland) and one general cluster with multifunctional proteins but implicated in occlusion progression (Figure 4). The latter includes proteins of extracellular matrix, blood, peroxisomes, and proteins involved in metabolic modulation. However, proteins of tissue-specific clusters are produced by meibomian glands, lacrimal glands, and conjunctival goblet cells and might indicate age- or disease-related changes in the tear proteome.

To determine the significance of proteins implicated in oxidative stress and immune response escalation, we obtained AUC measures using the ROC plot. We selected five proteins (S100A6, S100A8, S100A9, MSLN, and B2M) that meet the criteria of closest association with CRVO and ischemic condition and featured with the most significant alteration between the control group and subjects with CRVO (Figure 5).

The obtained results demonstrated satisfied AUC for each selected protein. The AUC measure varied from the least estimated to S100A6 (AUC=0.772) to a maximum value for S100A9 (AUC=0.952). It should be noticed, the most contributing proteins (S100A8, S100A9, and B2) belong to secreted proteins of the immune response and matrix-mediated regulation of cell migration, apoptosis regulation, and $\mathrm{MHC}-\mathrm{I}$ representation. Despite the great specificity and sensitivity of the ROC curve (Figure 5), we avoid combining these proteins into the biomarkers pattern since much more examination is required to establish the proper role of the pattern in CRVO pathogenesis.

\section{Discussion}

Besides age-related changes in the proteome, retinal vein occlusion (RVO) is accompanied by specific alterations in the matrix and hemostasis-associated proteins. The pivotal role of monitored changes is impaired blood outflow, so the retina suffers ischemic conditions upstream of the occlusion ${ }^{15}$. The ongoing anatomical changes induce an increase in VEGF and favor to drive the inflammatory condition ${ }^{16}$. Recent proteomic analysis of vitreous humor samples from RVO patients showed credible up-regulation of pro-inflammatory and immune-related proteins: C3 complement factor, CLU, VTN, and IGLL5 ${ }^{17}$. Although this small cohort of proteins is of interest, it only indicates common undergoing changes and cannot be used as markers. Animal model of laser-induced BRVO uncovered several interesting alarming proteins that were not reported previously as RVO-associated, but most of them are matrix-related (including laminin subunits, integrin, and actinin isoforms). Based on this evidence, the authors concluded that RVO is tightly associated with the matrix remodeling process as well as integrin and focal adhesion signaling ${ }^{18}$.

The study of animal laser-induced RVO revealed, that it could be distinguished from the control samples based on the proteomic data. The main input into discrimination made pro-inflammatory proteins, of which 
S100A12 was the most profoundly increased ${ }^{8}$. Our data also suggests that ischemic conditions in RVO patients might be associated with inflammation and mediated by immune-related proteins since S100A family proteins and B2M ( $\beta 2$-microglobulin) (Table 1 ) are significantly up-regulated in the RVO patients. These proteins construct a separate cluster on the protein-protein interaction map (S100A6, S100A8, and S100A9; Figure 4) and are tightly joined with matrix-related (ACTB) and metal-binding proteins (TF). Previous comparative studies of CRVO and non-ischemic ocular disease patients revealed that proinflammatory proteins level directly correlates with the severity of retinal ischemia ${ }^{19}$. If S100A6 is a prolactin receptor-associated protein mediating glucocorticoids secretion, while S100A9 and S100A8 both are regulators of cells migration acting in the defending mechanisms against inflammation, oxidative stress, and innate immune stimulation, one may conclude that these proteins indicate local inflammation as a consequence of CRVO ischemic condition.

The S100 family proteins were rigorously revied in the context of eye disease as promising markers patterns with a high predictive potency and disease monitoring value ${ }^{20}$. These proteins have been repeatedly screened in the tear and showed an ability to discriminate between dry eye disease and CRVO due to controversial regulation (upregulated in CRVO) $8,21,22$. These secreted proteins are typically well correlated with a significantly suppressed MHC-I peptide representation B2M protein (Table 1) and extracellular matrix proteins abundantly observed in our study, including PRR4, ACTB, MSLN, and CST3 (Table 1) indicating active immune response regarding chemokines activation. Interestingly, but it should be notified, that MSLN (mesothelin) has not been ever reported in tear proteome at either eye-related disease. The protein is generally mentioned as a target in the chemotherapy of different oncophenotypes, and mostly regarding solid tumors ${ }^{23}$.

The finding of MSLN in the tear was unexpected, however, if consider the beguiling idea of the increased level of extracellular matrix compounds as a biomarker for CRVO and glaucoma ${ }^{24-26}$, it seems possible the presence of MSLN due to its importance in cell adhesion. In consistence with our observation, ischemic condition at CRVO induce the expression of ocular-specific pro-fibrotic TGF- $\beta 2$ factor, that sufficiently promotes the growth of extracellular matrix ${ }^{26,27}$. Therefore, MSLN was established among up-regulated proteins in this study (Table 1). However, it should be admitted the matrix proteins are highly sensitive, so their alteration is generally a consequence of oxidative stress and inflammation, whereas the primary sign is depicted in hemostasis and mitochondria maintenance dysregulation. It has been reported, that patients with glaucoma and CRVO are characterized by irregular levels of GPX, SOD, and MDA, and typically present a higher level of these proteins even after surgery ${ }^{28,29}$.

The association of oxidative stress and macular degeneration with damaging and dysfunction of mitochondrial ${ }^{30}$. Moreover, with aging mitochondria become progressively more incomplete, thus CRVO can be considered as an age-related disease with a pivotal role in increasing ROS output ${ }^{31}$. In this study, the oxidative stress consequence is reflected in the decrease of mitochondria and mitochondria inner membrane organization processes (Figure 3), possibly indicating the prevalence of apoptosis and celldamaging. In oppose, processes related to cell response of topologically incorrect proteins and chaperon- 
cofactor proteins refolding and de novo proteins folding are substantially up-regulated in the proteome of patients with CRVO (Figure 3) along with chaperon proteins (Table 1).

While all retinal cells rely on ATP as a fuel source and the photoreceptors are the largest consumers requiring regular mitochondria functioning, hypothesized, that such cautioning processes (Figure 3) underline consequences of the impaired retinal hemostasis and accompanied tissue-damaging caused by the increased pro-inflammatory activity. Furthermore, stimulated mitochondrial oxidative phosphorylation contributes significantly to the increased ATP and, consequently, ROS generation and may cause protein folding and refolding processes in the endoplasmic reticulum ${ }^{32}$ and stimulates the production of inflammatory cytokines ${ }^{33}$. Notwithstanding, only a few reports can be found regarding the relation of oxidative stress with CRVO ${ }^{28}$, but much more reports review the relation with diabetic retinopathy ${ }^{34-36}$.

If considering oxidative stress as the paramount background event of CRVO, it is essential to unfurl the role of ROS scavengers and the related transport system as a possible victim of the boosted ROS generation and cytokines production. We found the local increase of transthyretin (Table1) also known as transthyretin (TTR) in the proteome of CRVO patients with a 0.88 frequency. The protein is mainly synthesized in the liver and is also found to be expressed in retinal pigment epithelial cells ${ }^{37}$. Apart from the pivotal role of TTR in the transport of thyroxine to the brain, circulating TTR also carries a retinol-binding protein (RBP) transporting and stabilizing retinol as an essential antioxidant agent. Due to high toxic potency, retinol is primarily stored in form of fatty acid esters. Vitamin A can efficiently neutralize thiol-radicals and stabilizes peroxide radicals being an important epigenetic factor preventing and reducing the risk of oxidative stress and inflammatory-related diseases ${ }^{38,39}$. The deficiency of TTR may aggravate the risk of oxidative stress and enhance local impairment of circulation and angiogenic processes, which is particularly established for cardiovascular and nondegenerative diseases ${ }^{40}$. On the other side of this matter, excessive circulating TTR provides a favorable environment for the transthyretin amyloidosis being involved in numerous ophthalmological pathologies ${ }^{37}$.

Despite most of the studies intend to assemble proteins in a panel of putative biomarkers, we are reluctant to build the decision-making pattern of CRVO biomarkers. Instead, we focused on the five most significantly altered proteins credibly associated with the pathogenesis of CRVO and capable of indicating the ongoing inflammation caused by the ischemic condition. We submitted S100A6, S100A8, S100A9, MSLN, and B2M proteins to estimate the area under the curve (Figure 5). The obtained measures of ROC for each protein satisfies specificity and sensitivity expectations. Although some of these proteins are repeatedly mentioned in the context of CRVO severity and onset, their combination might be a more proper item for consideration to figure out the very beginning of CRVO and to monitor the bases of ocular diseases treatment.

\section{Conclusion}

Tear proteome results have been reported in this study. Although we found a large proportion (505 proteins) of proteome shared between studied groups, results of the statistical analysis demonstrated no significant difference between the control group and patients with CRVO on the level of quantitative loading. In total, a 
cohort of 30 proteins has been attributed to up- or down-regulated in the CRVO group mostly providing the information about immune response, inflammatory and retinal hemostasis impairments processes. The profound decrease of B2M and immediate increase of S100A family proteins with the abundance of matrixassociated secreted proteins underlines the influence of local oxidative stress on cell migration and cytokines stimulated inflammatory reaction as a consequence of the progressing ischemic condition. In this study, we identified mesothelin (MSLN), which has never been reported in tear proteome before but mostly touched in regard to targeted therapy of solid tumors. We assumed the attribution of MSLN to matrix proteins set due to its importance in cell adhesion regulation and stimulated by the ocular-specific profibrotic TGF- $\beta 2$ factor.

Mitochondria maintenance proteins are the most sensitive indicators in response to escalated oxidative stress. It has been determined that processes associated with mitochondria biogenesis and mitochondria inner membrane formation (as a mitochondria repopulation) were significantly suppressed in the tear proteome of CRVO patients, whereas processes associated with proteins metabolism (de novo folding, chaperon cofactor-depended refolding, cellular response to topologically incorrect proteins) were prevalent in the biological processes' hierarchy. Besides, we have established an increased level of TTR in the tear. We suggested a deficient level of retinol-binding protein as a possible reason for the increased circulating TTR. Furthermore, due to TTR is generally increased in oxidative stress conditions (caused by the ischemic condition in certain cases), we supposed that the excess of TTR aggravated by the deficient of retinolbinding protein can be a risk factor of transthyretin amyloidosis as a possible dire consequence of the impaired retinal hemostasis and occlusion.

In summary, we assume that there are several promising proteins capable to highlight new insight into understating and evaluating the CRVO pathology. But the utility of these proteins in a part or whole is questionable until multiple examinations are being provided.

\section{Materials And Methods}

\section{Subjects and Ethical consideration}

Totally, 88 subjects ( 51 females (58\%) and 37 males (42\%); 66 (40 to 86 ) years old) participated in the study population, of them 30 subjects ( 20 females (67\%) and 10 males (33\%) with a median age of 77.5 years old (ranged between 61-86 years old) were enrolled in the control group and 58 subjects (31 females (53\%) and 27 males (47\%) with a median age of 61.5 years old (ranged between $40-89$ years old) were patients of the target group with central retinal vein occlusion (CRVO group). Among the case study group 34 subjects $(59 \%)$ were diagnosed with complete occlusion, 14 subjects $(24 \%)$ were characterized by incomplete or pre-occlusion conditions and 10 subjects (17\%) with thrombosis. All subject signed their informed consent to participate in the study. The study was approved by the Local Ethical Committee of the Russian Medical Academy of Continuous Professional Education (approval protocol no. 13 issued on November 26, 2019). The Approval was obtained in strict accordance with the tenets of the WMA Declaration of Helsinki on Biomedical Research Involving Human Subjects. All subjects were anonymized and no personal data can be disclosed with this paper. The detail of clinical records is presented in Table 2. 


\section{Samples collection and preparation}

To minimize the ocular surface irritation, tears samples were obtained from the inferior temporal tear meniscus without anesthesia and collected using the calibrated volumetric glass microcapillary (10- $\mu \mathrm{l}$ nominal calibrated volume; Blaubrand, Germany). Samples were stored at $-80^{\circ} \mathrm{C}$ and transported in dry ice for proteomic analysis. Totally, up to $100 \mu \mathrm{L}$ of each tear sample was collected.

The tear sample in a volume of $30 \mu \mathrm{L}$ was mixed with $120 \mu \mathrm{L}$ of methanol (J. T. Baker; the Netherlands) for proteins precipitation and centrifuged at $17,500 \times g$ acceleration at $15^{\circ} \mathrm{C}$ for 10 minutes (Centrifuge $5424 \mathrm{R}$, Eppendorf, Germany). The supernatant was discarded and the obtained precipitate was dissolved in $15 \mu \mathrm{L}$ of the denaturation solution consisted of $1 \%$ deoxycholic acid sodium salt (Sigma, Italy), $5 \mathrm{M}$ urea (Sigma, Italy), $6 \%$ acetonitrile (Carlo Erbo, France), $300 \mathrm{mM}$ sodium chloride (Fluka-Honeywell, Germany) buffered by $75 \mathrm{mM}$ triethylammonium bicarbonate to $\mathrm{pH} 8.5$ (Sigma, Switzerland) and supplied with freshly prepared $10 \mathrm{mM}$ tris-(2-carboxyethyl) phosphine (Sigma, St. Louis, MO, USA) for proteins reduction. Samples were incubated for $20 \mathrm{~min}$ at $45^{\circ} \mathrm{C}$ under continual stirring. Alkylation was supplied by the $2 \%$ solution of 4-vinylpyridine (Aldrich, the UK) in $30 \%$ isopropanol (Fisher Chemical, the UK) added to $0.2 \%$ of the final concentration and incubated for 20 minutes at ambient temperature in darkness. Following alkylation, the sample was diluted ten times with triethylammonium bicarbonate $50 \mathrm{mM}$ (pH 8.2). Insolution digestion with trypsin (Promega, Madison, WI, USA) resuspended to $200 \mathrm{ng} / \mu \mathrm{L}$ in $30 \mathrm{mM}$ acetic acid (Carlo Erba, France) was performed in two consequent steps at a 1:50 $(\mathrm{w} / \mathrm{w})$ ratio for $3 \mathrm{~h}$ at $37^{\circ} \mathrm{C}$. When digestion was completed, the reaction was quenched with $50 \%$ formic acid (Fisher Chemical, the UK) added to a $2 \%$ final concentration. Samples were centrifuged at $12,500 \times g$ for 10 minutes at $10^{\circ} \mathrm{C}$ to sediment insoluble deoxycholic acid. Ethylacetate (Carlo Erba, France) in a volume of $100 \mu \mathrm{L}$ was added to clean the supernatant from deoxycholic acid remnants, shacked vigorously, and centrifuged at $12,500 \times g$ for 10 minutes at $10^{\circ} \mathrm{C}$ again. The obtained clean supernatant was dried under a vacuum at $30^{\circ} \mathrm{C}$ for $30-40$ minutes, and the resulting pellet was reconstituted in $20 \mu \mathrm{L}$ of $0.5 \%$ formic acid.

\section{Mass spectrometry analysis}

Discovery proteomic analysis was performed on a high-resolution time-of-flight mass spectrometer Xevo G2-XS (Waters, the UK) equipped with a Z-spray electrostatic ionization source and operated in a positive ionization mode at a $2.8 \mathrm{kV}$ capillary voltage, $85 \mathrm{~V}$ cone voltage with offset to $115 \mathrm{~V}$. The desolvation gas flow rate was adjusted to $720 \mathrm{~L} / \mathrm{h}$ at a temperature of $410^{\circ} \mathrm{C}$, and the cone gas flow was $50 \mathrm{~L} / \mathrm{h}$ at a temperature of $150^{\circ} \mathrm{C}$. Precursor ions survey was conducted in a sensitivity analyzer mode within 300-1250 $\mathrm{m} / \mathrm{z}$ range within $235 \mathrm{~ms}$ of full duty cycle. Fragment ions we obtained after decomposition in CID mode at collision energy ramping within $14-42 \mathrm{eV}$ using argon as a collision. The acquisition was supported with an active online calibration by the lock-mass of $m / z=556.27$ (Leu-Enkephalin at $50 \mathrm{pg} / \mathrm{mL}$ continually injected at a flow rate of $5 \mu \mathrm{L} / \mathrm{min}$ ) applied every $30 \mathrm{~s}$ with isolation tolerance of $3 \mathrm{mDa}$.

Samples were separated using an Acquity H-Class UPLC system (Waters, the UK) and loaded in a volume of $3 \mu \mathrm{L}$ (totally $3 \mu \mathrm{g}$ of protein fraction on-column loading) onto an Acquity ${ }^{\mathrm{Tm}} \mathrm{UPLC}$ BEH C18 $(2.1 \times 50 \mathrm{~mm}, 1.7$ $\mu \mathrm{m}$ particle size; Waters, the UK) column heated to $50^{\circ} \mathrm{C}$ with the pre-installed in-line $0.2 \mu \mathrm{m}$ filter. at a flow 
rate of $0.3 \mathrm{~mL} / \mathrm{min}$. Peptides were separated in a gradient of mobile phase $A$ (water) and mobile phase $B$ (acetonitrile) both supplied with $0.1 \%$ formic acid and $0.015 \%$ trifluoracetic acid using the following gradient scheme: $0-2.5 \mathrm{~min} 3 \%$ of $B$, then raising the $B$ to $17 \%$ at $31.5 \mathrm{~min}$, then raising the $B$ to $37 \%$ at 45 min and rapid increasing of $B$ to $97 \%$ at $47.5 \mathrm{~min}$. The washing $B$ was kept in the isocratic mode to $51 \mathrm{~min}$ at $0.45 \mathrm{~mL} / \mathrm{min}$ flow rate, following smooth decreasing to the initial condition ( $3 \%$ of $\mathrm{B}$ ) at $53.5 \mathrm{~min}$ and equilibration for the next $6 \mathrm{~min}$ at $0.3 \mathrm{~mL} / \mathrm{min}$.

\section{Proteomic data analysis}

Raw data files were processed using PLGS (Protein Lynx Global Server, version 3.0.3, Waters, the UK) search engine against human protein amino acid sequences database obtained from UniProt KB (release May 2021) as a FASTA file. Reversed concatenated decoy sequences were added to the database automatically to estimate a false positive rate. The search was performed at a precursor mass tolerance of $20 \mathrm{ppm}( \pm 10$ $\mathrm{ppm}$ tolerance window) and a fragment mass tolerance of $0.008 \mathrm{Da}( \pm 4 \mathrm{mDa}$ tolerance window). Searching included $S$-pyridilethylation as a fixed modification, and oxidized methionine and Q/N deamidation as variable modifications. The minimal peptide length was fixed to eight amino acids, and only one internal missed cleavage was allowed. The false discovery rate (FDR) at $1 \%$ was determined for peptide and protein identification by accumulating the reverse database hits. Quantitative loading was estimated using a UPS-2 (Merck) dynamic range universal proteomic standards set, that contains 48 proteins in a known concentration range covering five orders of magnitude. The quantitative measurement has been performed by applying the Creatine kinase M-type (P06732 UniProt accession number) and BH3-interacting domain death agonist (P55957 UniProt accession number) included in the UPS-2 set at 500 fmoles and 50 fmoles amounts, correspondingly.

\section{Statistical data analysis}

Proteins that meet the criterion of unicity by the presence of at least one unique (proteotypic) peptide apart of isoform-specific peptides, were extracted for the statistical analysis following the proteins identification search. The identified group-specific proteomes were assessed for similarity and the shared part of proteome was extracted for the principal component analysis (PCA). Protein intensity was estimated as the normalized summed peptide intensities belonged to the certain protein and the resulting matrix of intensities was used for the quantification based on the calculation of intensity medians for each protein within studied groups. Wilcoxon test with a threshold of $p<0.05$ was applied to groups of study to revealed outliers and significant differences in a quantitative loading. A measure of protein abundance was represented as a median value fold changes (FC) ratio toward the control group and calculated based on the absolute concentration sampled from the UPS-2-based quantitative analysis. Proteins with a frequency of at least 0.6 within each studied group, and beyond the log-scaled fold change cut-off of FC $>1$ or FC $<-1$ at a significance $p$-values of less than 0.05 (pairwise $t$-test test) were considered as significant in the quantitative property. Significantly altered proteins were submitted for functional and pathways analysis at a $q$-value threshold less than $q<0.01$ using the Cytoscape (version 3.8.2) software. Pathways and network reconstruction were performed in a STRING-based mode, and the disease-related mode by employing the retinal vein occlusion-related proteins open access network as a source for the network customization and reconstruction. Quantitative measures were attributed to the customized protein network and proteins were 
repopulated by applying the FDR $<0.01$ percolation filter. Proteins enriched by the $\mathrm{GO}$ terms of biological processes (GO database release of September 2021) were rendered with a similarity coefficient of more than 0.7 to refine the proteins interaction network with a burden of quantitative property attribution.

Analysis of biological processes direction and elimination of redundant GO-terms attributed to the enriched protein was performed in support of Rovigo (GO database update of July 02, 2021; UniProt-to-GO mapping database update of July 17, 2021) at a $p<0.001$ and Resnik semantic similarity measure. Arear under the curve (AUC) using a ROC operator was plotted for the most significantly altered proteins associated with the CRVO to determine the meaningfulness of proteins specificity and sensitivity to certain pathology.

\section{List Of Abbreviations (In Alphabetic Order)}

BRVO - Branch Retinal Vein Occlusion;

CDC14C - Dual specificity protein phosphatase CDC14C;

CLU - clusterin;

CRVO - central retinal vein occlusion;

FC - fold changes;

FDR - false discovery rate;

G6PD - glucose-6-phosphate dehydrogenase;

GO - gene ontology;

GPX - Glutathione peroxidase;

ICAM1 - intercellular adhesion molecule 1;

ITPR1 - Inositol 1,4,5-trisphosphate receptor type 1;

LTF - Lactotransferrin;

MDA - Malate dehydrogenase;

MSLN - mesothelin;

PCA - principal component analysis;

PLGS - Protein Lynx Global Server;

RBP - retinol-binding protein;

RVO - retinal vein occlusion; 
SOD - superoxide dismutase [Cu-Zn];

TMSB10 - Thymosin beta-10;

TTR - transthyretin;

UPS - universal proteomic standard;

VEGF - vascular endothelial growth factor;

\section{Declarations}

\section{Acknowledgments}

This work was financed by the Ministry of Science and Higher Education of the Russian Federation within the framework of state support for the creation and development of World-Class Research Centers "Digital Biodesign and Personalized Healthcare", no. 75-15-2020-913.

\section{Authors Contribution}

Samples collection, samples preparation, and data curation - S.A.U; study design - L.K.M.; data curation K.I.T.; statistical analysis - A.A.S.; data validation and design of experiment - K.A.M.; data analysis and conceptualization - A.T.K.; project management - A.L.K.; writing the original draft of the manuscript A.T.K.; writing and editing the final version of the manuscript - A.T.K and A.L.K.

\section{Conflict of interests}

The authors declared no conflict of interests

\section{References}

1. Cugati, S., Wang, J. J., Rochtchina, E. \& Mitchell, P. Ten-year incidence of retinal vein occlusion in an older population: the Blue Mountains Eye Study. Arch. Ophthalmol. (Chicago, III. 1960) 124, 726-732 (2006).

2. Laouri, M., Chen, E., Looman, M. \& Gallagher, M. The burden of disease of retinal vein occlusion: review of the literature. Eye (Lond), 25, 981-988 (2011).

3. Mir, T. A. et al. Changes in Retinal Nonperfusion Associated with Suppression of Vascular Endothelial Growth Factor in Retinal Vein Occlusion., 123, 625-341 (2016).

4. Yong, H., Qi, H., Yan, H., Wu, Q. \& Zuo, L. The correlation between cytokine levels in the aqueous humor and the prognostic value of anti-vascular endothelial growth factor therapy for treating macular edema resulting from retinal vein occlusion. Graefe's Arch. Clin. Exp. Ophthalmol. = Albr. von Graefes Arch. fur Klin. und Exp. Ophthalmol, https://doi.org/10.1007/s00417-021-05211-2 (2021).

5. Jung, S. H., Kim, K. A., Sohn, S. W. \& Yang, S. J. Association of aqueous humor cytokines with the development of retinal ischemia and recurrent macular edema in retinal vein occlusion. Invest. 
Ophthalmol. Vis. Sci, 55, 2290-2296 (2014).

6. Yuan, X. et al. Quantitative proteomics: comparison of the macular Bruch membrane/choroid complex from age-related macular degeneration and normal eyes. Mol. Cell. Proteomics, 9, 1031-1046 (2010).

7. Kotwal, R. S. et al. Central retinal vein occlusion in an Army Ranger with glucose-6-phosphate dehydrogenase deficiency. J. Spec. Oper. Med. a peer Rev. J. SOF Med. Prof, 9, 59-63 (2009).

8. Cehofski, L. J. et al. IL-18 and S100A12 Are Upregulated in Experimental Central Retinal Vein Occlusion.Int. J. Mol. Sci.19, (2018).

9. Vogl, T. et al. S100A12 is expressed exclusively by granulocytes and acts independently from MRP8 and MRP14. J. Biol. Chem, 274, 25291-25296 (1999).

10. Zhang, Y. et al. Activation of the mitochondrial apoptotic pathway in a rat model of central retinal artery occlusion. Invest. Ophthalmol. Vis. Sci, 46, 2133-2139 (2005).

11. Nordgaard, C. L., Karunadharma, P. P., Feng, X., Olsen, T. W. \& Ferrington, D. A. Mitochondrial proteomics of the retinal pigment epithelium at progressive stages of age-related macular degeneration. Invest. Ophthalmol. Vis. Sci, 49, 2848-2855 (2008).

12. Xu, H. J., Li, Q. Y., Zou, T. \& Yin, Z. Q. Development-related mitochondrial properties of retinal pigment epithelium cells derived from hEROs. Int. J. Ophthalmol, 14, 1138-1150 (2021).

13. Nordgaard, C. L. et al. Proteomics of the retinal pigment epithelium reveals altered protein expression at progressive stages of age-related macular degeneration. Invest. Ophthalmol. Vis. Sci, 47, 815-822 (2006).

14. Cehofski, L. J. et al. Retinal proteome changes following experimental branch retinal vein occlusion and intervention with ranibizumab. Exp. Eye Res, 152, 49-56 (2016).

15. Cehofski, L. J., Honoré, B., Vorum, H. A. \& Review Proteomics in Retinal Artery Occlusion, Retinal Vein Occlusion, Diabetic Retinopathy and Acquired Macular Disorders. Int. J. Mol. Sci.18, (2017).

16. Campochiaro, P. A. et al. Pro-Permeability Factors After Dexamethasone Implant in Retinal Vein Occlusion; the Ozurdex for Retinal Vein Occlusion (ORVO) Study. Am. J. Ophthalmol, 160, 313-32119 (2015).

17. Reich, M. et al. Proteomic Analysis of Vitreous Humor in Retinal Vein Occlusion. PLoS One, 11, e0158001 (2016).

18. Cehofski, L. J. et al. Proteins involved in focal adhesion signaling pathways are differentially regulated in experimental branch retinal vein occlusion. Exp. Eye Res, 138, 87-95 (2015).

19. Noma, H., Funatsu, H. \& Mimura, T. Vascular endothelial growth factor and interleukin- 6 are correlated with serous retinal detachment in central retinal vein occlusion. Curr. Eye Res, 37, 62-67 (2012).

20. Tamhane, M., Cabrera-Ghayouri, S., Abelian, G. \& Viswanath, V. Review of Biomarkers in Ocular Matrices: Challenges and Opportunities. Pharm. Res, 36, 40 (2019).

21. Srinivasan, S., Thangavelu, M., Zhang, L., Green, K. B. \& Nichols, K. K. iTRAQ quantitative proteomics in the analysis of tears in dry eye patients. Invest. Ophthalmol. Vis. Sci, 53, 5052-5059 (2012).

22. Ma, J. Y. W., Sze, Y. H., Bian, J. F. \& Lam, T. C. Critical role of mass spectrometry proteomics in tear biomarker discovery for multifactorial ocular diseases (Review).Int. J. Mol. Med.47, (2021). 
23. Hassan, R. et al. Mesothelin Immunotherapy for Cancer: Ready for Prime Time? J. Clin. Oncol. Off. J. Am. Soc. Clin. Oncol, 34, 4171-4179 (2016).

24. Knepper, P. A. et al. Aqueous humor in primary open-angle glaucoma contains an increased level of CD44S. Invest. Ophthalmol. Vis. Sci, 43, 133-139 (2002).

25. Agarwal, P., Daher, A. M. \& Agarwal, R. Aqueous humor TGF- $\beta 2$ levels in patients with open-angle glaucoma: A meta-analysis. Mol. Vis, 21, 612-620 (2015).

26. Igarashi, N. et al. Crosstalk between transforming growth factor $\beta$-2 and Autotaxin in trabecular meshwork and different subtypes of glaucoma. J. Biomed. Sci, 28, 47 (2021).

27. Picht, G., Welge-Luessen, U., Grehn, F. \& Lütjen-Drecoll, E. Transforming growth factor beta 2 levels in the aqueous humor in different types of glaucoma and the relation to filtering bleb development. Graefe's Arch. Clin. Exp. Ophthalmol. = Albr. von Graefes Arch. fur Klin. und Exp. Ophthalmol, 239, 199207 (2001).

28. Masuda, T., Shimazawa, M. \& Hara, H. Retinal Diseases Associated with Oxidative Stress and the Effects of a Free Radical Scavenger (Edaravone). Oxid. Med. Cell. Longev. 2017, 9208489 (2017).

29. Flammer, J. et al. The eye and the heart. Eur. Heart J, 34, 1270-1278 (2013).

30. Zorov, D. B., Juhaszova, M. \& Sollott, S. J. Mitochondrial reactive oxygen species (ROS) and ROSinduced ROS release. Physiol. Rev, 94, 909-950 (2014).

31. Davalli, P., Mitic, T., Caporali, A., Lauriola, A. \& D’Arca, D. R. O. S. Cell Senescence, and Novel Molecular Mechanisms in Aging and Age-Related Diseases. Oxid. Med. Cell. Longev. 2016, 3565127 (2016).

32. Moserova, I. \& Kralova, J. Role of ER stress response in photodynamic therapy: ROS generated in different subcellular compartments trigger diverse cell death pathways. PLoS One, 7, e32972 (2012).

33. Juel, H. B., Faber, C., Svendsen, S. G., Vallejo, A. N. \& Nissen, M. H. Inflammatory cytokines protect retinal pigment epithelial cells from oxidative stress-induced death. PLoS One, 8, e64619 (2013).

34. Kowluru, R. A. Diabetic retinopathy, metabolic memory and epigenetic modifications. Vision Res, 139, 30-38 (2017).

35. Kowluru, R. A. Diabetic Retinopathy: Mitochondria Caught in a Muddle of Homocysteine.J. Clin. Med.9, (2020).

36. Kowluru, R. A. Mitochondria damage in the pathogenesis of diabetic retinopathy and in the metabolic memory associated with its continued progression. Curr. Med. Chem, 20, 3226-3233 (2013).

37. Minnella, A. M. et al. Ocular Involvement in Hereditary Amyloidosis.Genes (Basel). 12, (2021).

38. Palace, V. P., Khaper, N., Qin, Q. \& Singal, P. K. Antioxidant potentials of vitamin A and carotenoids and their relevance to heart disease. Free Radic. Biol. Med, 26, 746-761 (1999).

39. Carazo, A. et al. Vitamin A Update: Forms, Sources, Kinetics, Detection, Function, Deficiency, Therapeutic Use and Toxicity.Nutrients13, (2021).

40. Kaysen, G. A. \& Eiserich, J. P. The role of oxidative stress-altered lipoprotein structure and function and microinflammation on cardiovascular risk in patients with minor renal dysfunction. J. Am. Soc. Nephrol, 15, 538-548 (2004). 


\section{Figures}
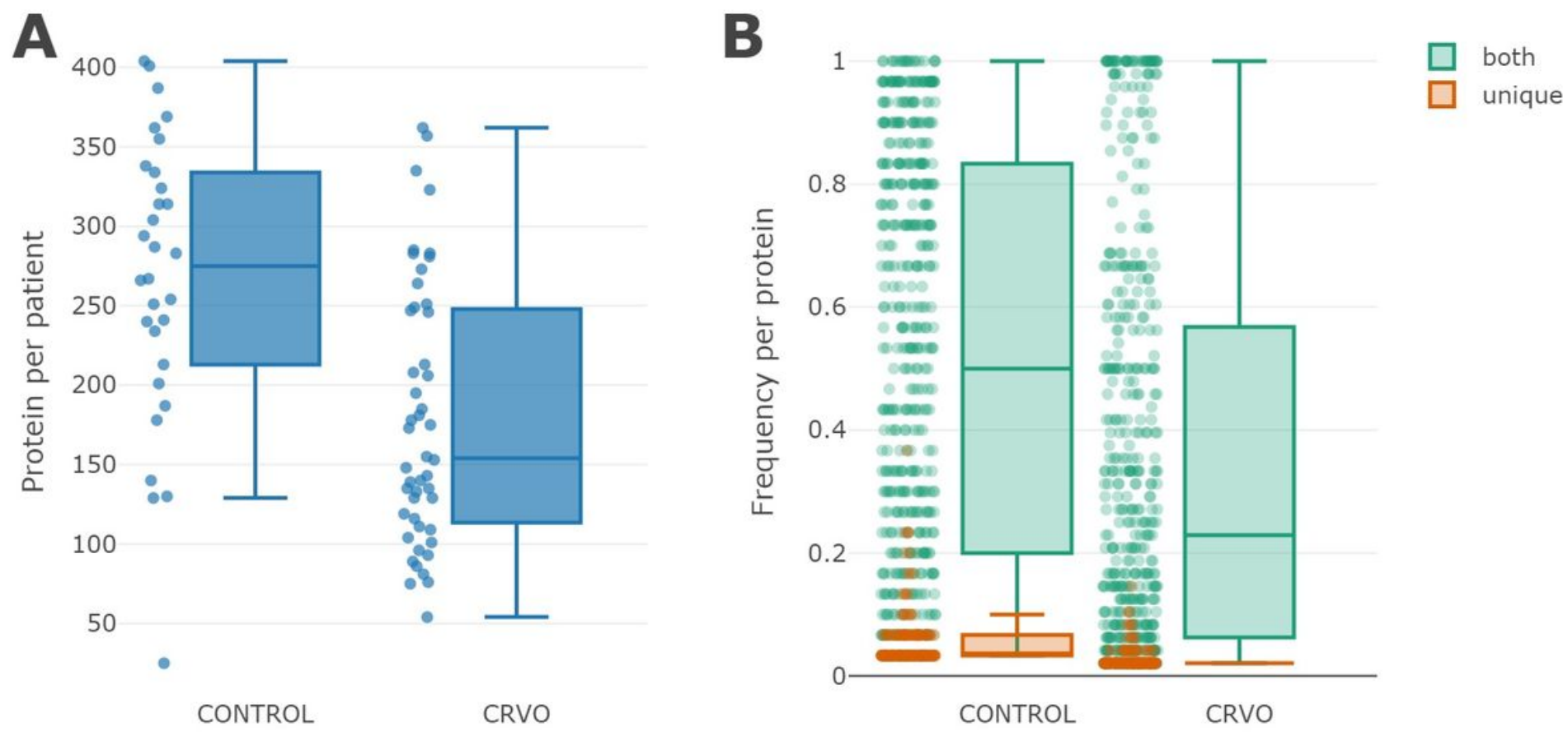

Figure 1

Box-plot of the proteome size (A) and frequency (B) distribution among subjects on the control and CRVO groups. The median size of individual proteins in the control group was found to be 275 protein identification (with a q1-q3 interquartile range between 213-334 proteins), whereas the median proteome size in the CRVO group was 154 proteins (with a q1-q3 interquartile range of 114-248 proteins (A). Frequency distribution of proteins identified within the control and CRVO group. The majority of groupspecific proteins (brown color) are fall between 0.03-0.37 frequency in the control group and between 0.020.14 frequency among subjects with CRVO. Proteins of the shared part (green color) of the combined proteome are met with a median frequency of 0.5 (q1-q3 interquartile range of $0.2-0.83$ ) in the control group and with a median frequency of 0.23 (q1-q3 interquartile range of $0.06-0.57$ ) in CRVO group (B). 
A

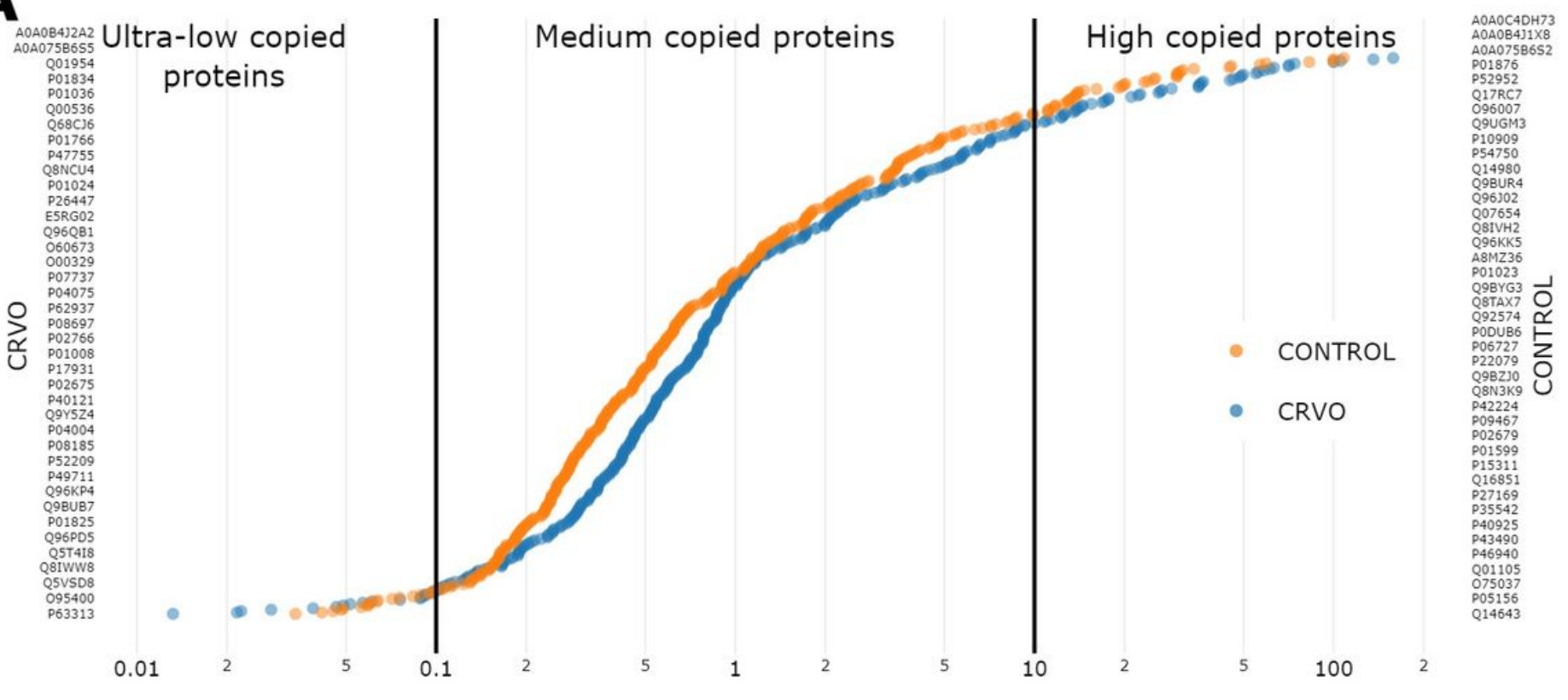

Median, fmoles per ng

B

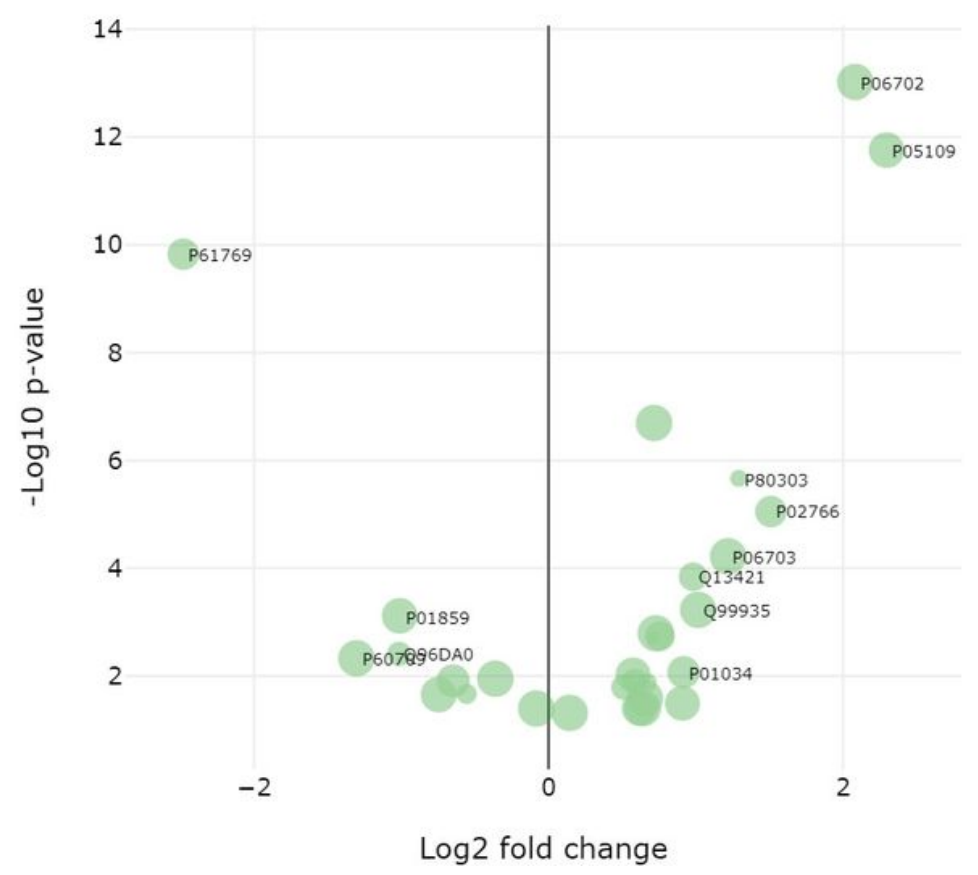

C

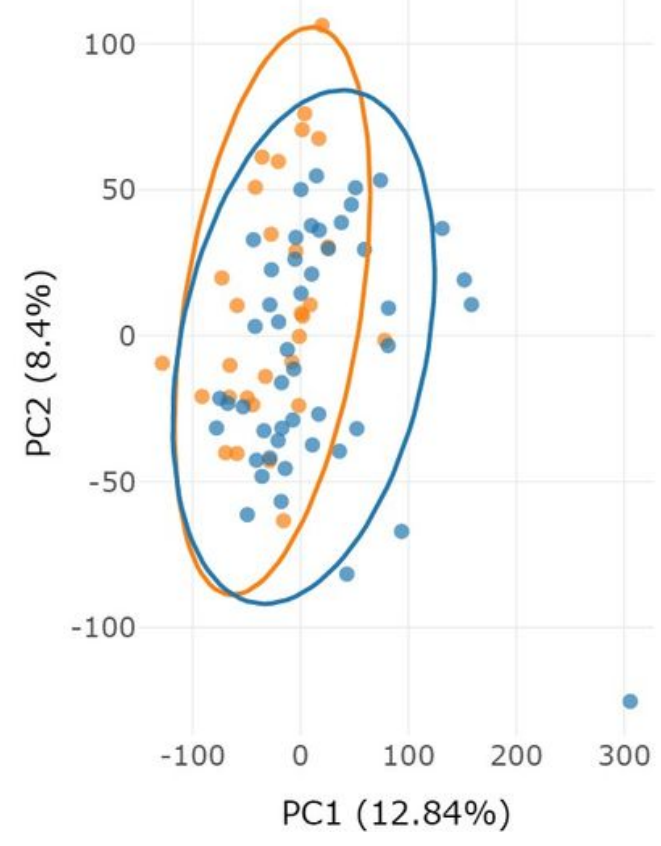

Figure 2

Distribution of proteins quantitative property within the combined proteome of control and CRVO groups. The largest proportion (up to 78\%) is covered by medium-copied proteins between $0.1-10 \mathrm{fmoles} / \mathrm{ng}$. The rest fraction can be split between low-copied (0.01-0.1 fmoles/ng) proteins (up to 8\%) and high-copied (more than $10 \mathrm{fmoles} / \mathrm{hg}$ ) proteins accounted up to $14 \%$ of the tear proteome size (A). Volcano-plot scattering of 31 significantly ( $p<0.05$, Wilcoxon test) differed proteins (22 upregulated (log $F C>1)$ and 9 downregulated (log FC $<-1)$ proteins) between the control group and CRV subjects (B). Principal 
components analysis revealed no significant difference between groups of study with the contribution of $\mathrm{PC} 1=12.84 \%$ and $\mathrm{PC} 2=8.4 \%(\mathrm{C})$.

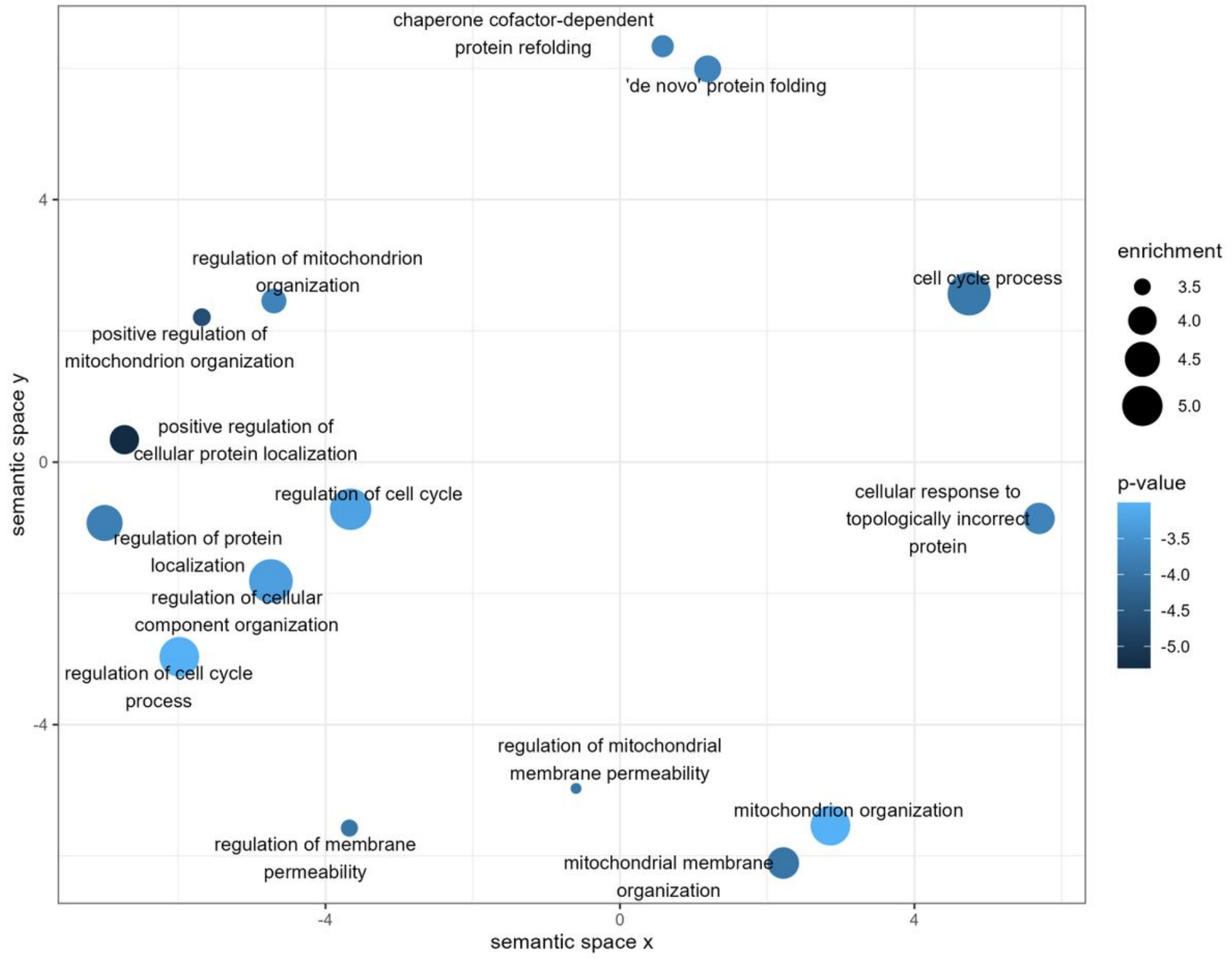

\section{Figure 3}

Distribution and prevalence of the GO biological processes terms (filtered at $p<0.001$ ) associated with the set of significantly differed proteins found between the control and CRVO groups. The semantic analysis is based on the Resnik algorithm and measures the similarity between the enriched ontology terms after the elimination of redundant terms. The defined enrichment measure (circles size) defines relative abundance and the direction of a certain biological process within the study group (CRVO) relative to the control groups. The majority of processes attributed to cell cycle and mitochondria organization are significantly depleted and abolished, while the regulation of improperly folded proteins and stress response reaction are organized in the enhanced acting cluster. 


\section{Retinal vein occlusion (tear)}
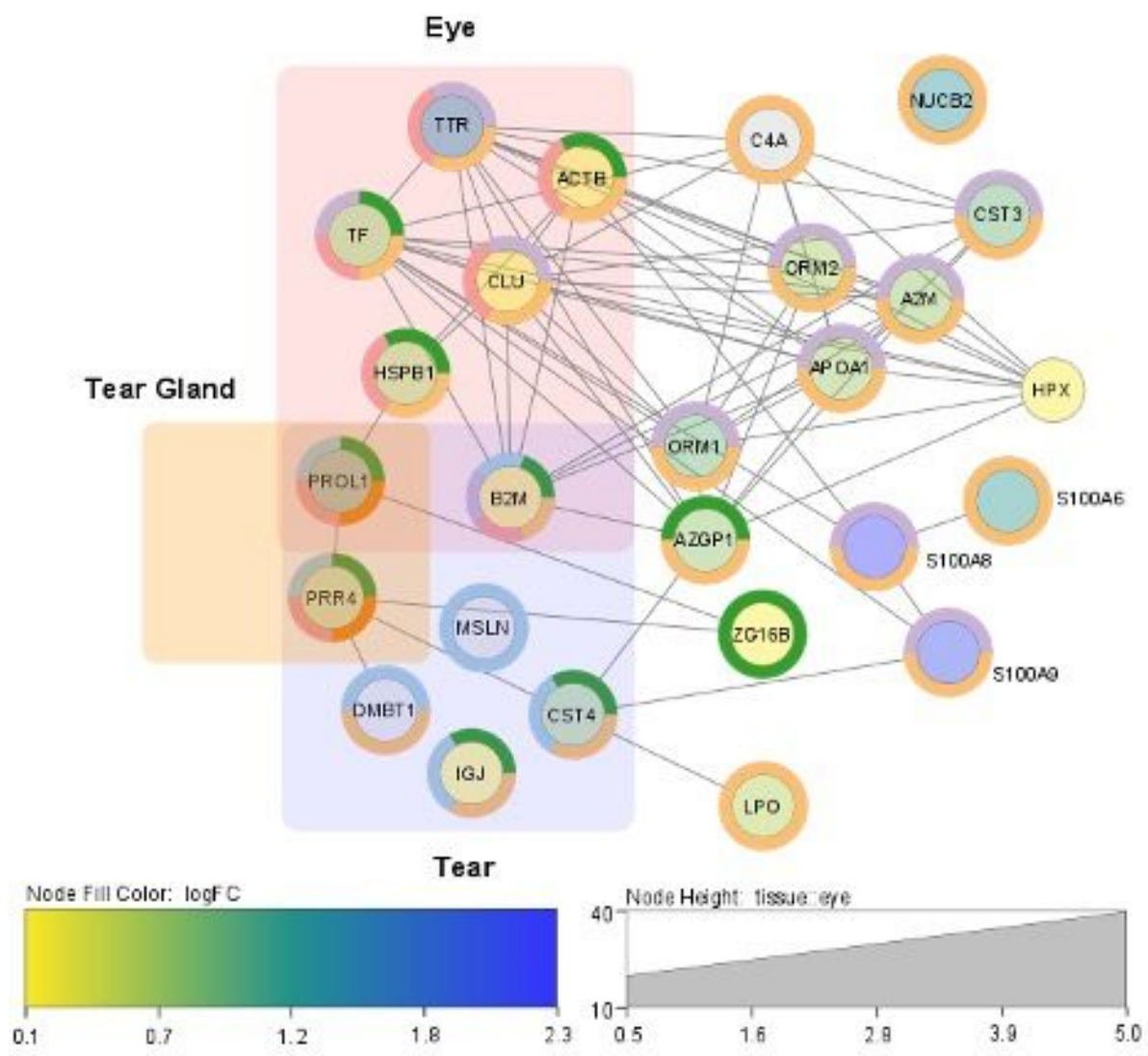

Figure 4

The reconstructed map of protein-protein interactions between the significantly differed proteins. The map is reconstructed in the context of retinal vein occlusion pathogenesis, tissue (source) specificity (such as tear gland, tear, and eye), and attributed with a quantitative loading of the measured proteins (color-scaled bar). The node height level indicates the confidence of proteins interaction and normalized to eye tissue specificity. Circles color indicated the prevalent biological processes contributing to the CRVO progression and taken by mapped proteins (vesicle-mediated transport (magenta); defense response (cyan); retina hemostasis (green), regulation of immune system (orange), cell migration, and extracellular matrix organization (blue)). 


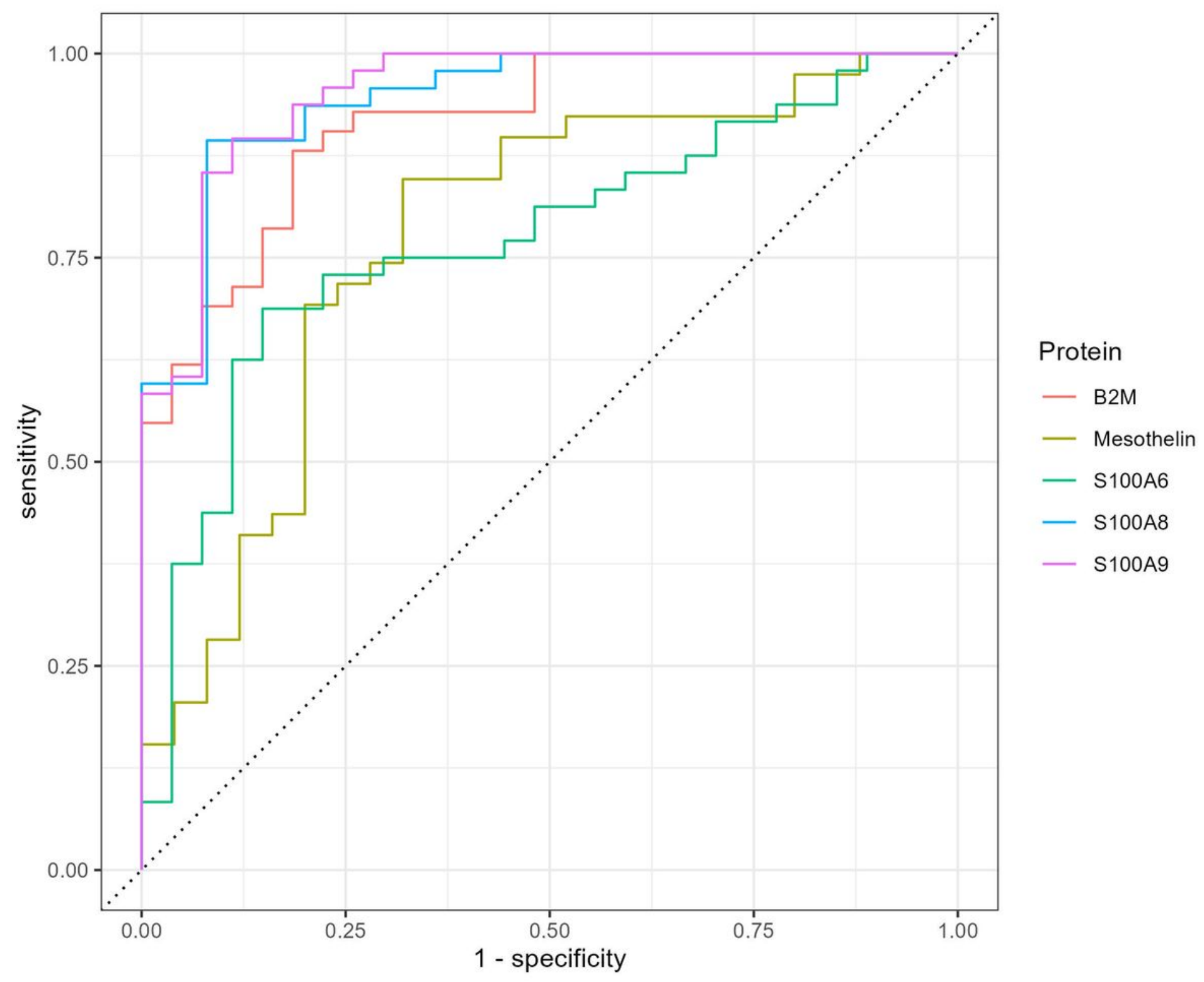

Figure 5

Receiver operating characteristic (ROC) plot of the area under the curve (AUC) for the most significantly altered proteins credibly associated with the CRVO pathology and the caused ischemic condition. The ROC curves have been plotted for S100A9 (AUC is 0.952), S100A8 (AUC is 0.945), B2M (AUC is 0.915), MSLN (AUC is 0.775), and S100A6 (0.772).

\section{Supplementary Files}


This is a list of supplementary files associated with this preprint. Click to download.

- SupplementalMaterialv1.1.xIsx 